Eskişehir Osmangazi Üniversitesi İlahiyat Fakültesi Dergisi Journal of Eskişehir Osmangazi University Faculty of Theology ISSN: 2147-8171

\title{
Sosyal Bir Hastalık ve Gayrimeşru Bir Evlilik: "Nikâhu'l-Makt"
}

\section{A Social ìllness And An İllegal Marriage: "Nikâh al Makt"}

\section{Dr. Öğr. Üyesi Mustafa Harun KIYLIK}

Van Yüzüncü Yıl Üniversitesi, i̇lahiyat Fakültesi, İslam Hukuku Anabilim Dalı Asst. Prof.,Van Yuzuncu Yll University, Faculty of Theology, Department of Islamic Law, Van, Turkey. harunkiylik@gmail.com

(D) 0000-0002-8238-0144

\begin{tabular}{lcr}
\multicolumn{3}{c}{ Makale Bilgisi / Article Information } \\
& Makale Türü / Article Type Araştırma Makalesi / Research Article \\
Geliş Tarihi / Received & Kabul Tarihi / Accepted & Yayın Tarihi / Published \\
27 Haziran / June 2021 & 13 Eylül / September 2021 & 23 Eylül / September 2021
\end{tabular}

\section{Atıf Bilgisi / Cite as:}

Kıylık, Mustafa Harun. “Sosyal Bir Hastalık ve Gayrimeşru Bir Evlilik: “Nikâhu'l-Makt””, Eskişehir Osmangazi Üniversitesi İlahiyat Fakültesi Dergisi 8/2 (Eylül 2021), 354-376.

http://doi.org/1051702/esoguifd.958137

İntihal / Plagiarism: Bu makale, en az iki hakem tarafindan incelenmiş ve intihal içermediği teyit edilmiştir. / This article has been reviewed by least two referees and scanned via a plagiarism software.

Copyright @ Published by Eskişehir Osmangazi Üniversitesi, İlahiyat Fakültesi /Eskişehir Osmangazi University, Faculty of Theology Bütün hakları saklıdır. / All right reserved. https://dergipark.org.tr/tr/pub/esoguifd

CC BY-NC 4.0 This paper is licensed under a Creative Commons Attribution-NonCommercial License

Etik Beyanı / Ethical Statement: Bu çalışmanın hazırlanma sürecinde bilimsel ve etik ilkelere uyulduğu, yararlanılan tüm çalışmaların kaynakçada belirtildiği ve bu araştırmanın desteklenmesi için herhangi bir dış fon almadıkları yazar tarafından beyan olunur / It is declared by the author that scientific and ethical principles have been followed while carrying out and writing this study; that all the sources used have been properly cited; that no external funding was received in support of the research. 
Kiylık, A Social illness And An İllegal Marriage: "Nikâh al Makt"

\section{Sosyal Bir Hastalık ve Gayrimeşru Bir Evlilik: "Nikâhu'l-Makt"*}

Öz • Sağlıklı bir toplum, geleceğe emin adımlarla ilerlemek isteyen her millet için büyük önemi haizdir. Bu da ancak sağlıklı bir aile yapısı ile mümkündür. Câhiliye dönemi Arap toplumunda birçok alanda olduğu gibi aile hayatında da bir disiplin yoktu. Duyulduğu zaman insanların tüylerini ürpertecek türden evlilik, birliktelik ve boşama şekilleri yerleşik bir hal almıştı. Vahiyden uzak yaşanan hayat, insanları sosyal, ekonomik ve ahlaki alanlarda infiale sebebiyet verecek tasarruflarda bulunmaya sevk ettiği için, doğru yoldan sapan bu topluma ilahi müdahale kaçınılmaz olmuş ve aile hayatı dâhil tüm alanlardaki yanlış uygulamalar kaldırılmıştır. İslâm'da soy bağı ve nesillerin korunması büyük ehemmiyet arz ettiği için sadece evlenilmesi haram olan kişilerin kimler olduğunun beyan edilmesi ile yetinilmemiş, aileye yönelik başka tedbirler de alınmıștır. Bu çalışmada, câhiliye döneminde sosyal bir hastalık olarak uygulama alanı bulan ve literatüre "nikâhu'l-makt" (nefret evliliği) şeklinde geçen evlilik türü, yasaklandığı ayet çerçevesinde ele alınmış, söz konusu nikâhın failine ne tür bir ceza verileceği hususu mevcut görüş ayrılıkları çerçevesinde incelenmiştir.

Anahtar Kelimeler: İslâm Hukuku, Nikâhu'l-Makt, Nisâ Sûresi, Haram, Câhiliye Dönemi.

\section{A Social İllness And An İllegal Marriage: "Nikâh al Makt"}

Abstract $>$ A healthy society is of great importance for every nation that wants to take firm steps towards the future. Such a society is only possible with a healthy family structure. There was no discipline in family life as in many other fields in Arab society during the Age of Ignorance. The forms of marriage, adultery, and divorce that made people nervous were common. Divine intervention was inevitable in this society that deviated from the right path, as the life that lived away from revelation prompted people to make savings that would cause indignation in social, economic and moral fields. In this direction, after establishing a society with strong beliefs, wrong practices in all areas including family life were eliminated. Since descent and protection of generations are important in Islam, it is not contented with explaining who the people who are forbidden to marry are, but other measures have been taken for the family. In this study, the type of marriage, which found an application area as a social disease in the period of "câhiliye" and which was mentioned in the literature as "nikâhu'l-maqt" (hate marriage) was discussed. In addition, the issue of what kind of punishment will be given to the perpetrator of this marriage has been examined within the framework of existing differences of opinion.

Keywords: Islamic Law, Nikâhu'l-Maqt, Surah an-Nisaâ, Forbidden, Ignorance Period.

\footnotetext{
* Bu makale 2020'de düzenlenen 4. Uluslararası Ahmed-i Hani Sempozyumunda sözlü olarak sunulan aynı başlıklı bildiri metninin yeniden gözden geçirilip geliştirilmiş halidir.
} 
Kıylık, Sosyal Bir Hastalık ve Gayrimeşru Bir Evlilik: "Nikâhu'l-Makt"

\section{Giriş}

İnsan, ruh ve bedenden müteşekkil bir varlıktır. Kimi durumlarda ruh ve bedene musallat olan bazı arızalar, ruhi ve fiziki rahatsızlıklara sebebiyet verir. Ruhi/zihni ve bedeni rahatsızlıkların yanı sıra manevi/ahlaki hastalıklar da söz konusu olup bireysel olarak başlayan bu hastalıklar, sosyal bir varlık olan insanın çevresiyle etkileşimi ile birlikte diğer insanlara da sirayet eder. Toplumsal hastalıklardan birini de gayrimeşru veya gayriahlaki birliktelikler ve nikâhlar oluşturmaktadır. Gayrimeşru birliktelikler, zina eylemini ifade ederken gayrimeşru nikâhları, zina fiiline nikâh zırhının giydirilmesi şeklinde bir ameliye olarak görmek mümkündür.

Sözlükte "bir araya getirme, evlilik ve cinsel ilişki" gibi anlamlara gelen "nikâh" kelimesi ${ }^{1}$ fıkıhta "şer'an aranan şartlar çerçevesinde aralarında evlenme engeli bulunmayan bir erkekle bir kadının hayatlarını geçici olmaksızın birleştirmelerini sağlayan akdi” ve bu yolla eşler arasında meydana gelen evlilik ilişkisini ifade eder. Arapçada zevâc kökünden türeyen kelimeler yaygın olarak bu anlamlarda kullanılır. ${ }^{2}$ İslâm'da evliliğin gayelerinden biri de neslin devamını sağlamaktır ki bu da ancak meşru bir cinsî münasebet ile mümkündür. ${ }^{3}$

Nikâh akdi Kur'ân'da, erkeğin kadına verdiği sağlam bir teminat olarak nitelendirilmiştir. ${ }^{4}$ Ailenin temelini oluşturan evlilik, ilahi dinlerin tümünde eşlerin, insan soyunun devamını sağlamalarına ve kendilerine has bir mahremiyet alanı oluşturmalarına imkân tanıyan yegâne meşru ilişki olarak kabul edilmiştir. ${ }^{5}$ Klasik fıkıh kaynaklarında nikâh kelimesi evlilik akdini, bağını ve eşler arasındaki hukukî ilişkiyi ifade etmektedir. ìlk dönem fikıh kitaplarında nikâhın öneminden, şartlarından, sonuçlarından ve evliliği sona erdiren durumlardan genişçe bahsedildiği halde, muhtemelen anlam ve mahiyeti çok iyi bilindiği için nikâh akdi terim olarak tarif edilmemiştir. Daha sonraki dönemlerde kaleme alınan eserlerde ise nikâh, "eşlerin meşru ölçüler dâhilinde cinsel açıdan karşllıklı olarak istifade edebilmesini helal kılan akit" şeklinde tarif edilmiş ${ }^{7}$ ve evlenme engelleri hassasiyetle işlenmiştir. Bu manilerden biri olan akrabalık ve hısımlığın evliliğe engel olması, aslında bir kaide olarak tüm dinlerde, hukuk ve ahlak

\footnotetext{
${ }^{1}$ Ebü'l-Fazl Cemâlüddîn İbn Manzûr, Lisânü'l-'Arab, (Beyrut: Dâru Sâdır, 1414), “nkh”, 2/625; Muhammed ez-Zebîdî, Tâcu'l-arûs, (b.y.: Dârü'l-Hidâye, ts.), “nkh”, 7/195.

${ }^{2}$ Fahrettin Atar, “Nikâh”, Türkiye Diyanet Vakfi İslâm Ansiklopedisi (İstanbul: TDV Yayınları, 2007), 33/112.

${ }^{3}$ Bk. en-Nisâ, 4/25; en-Nûr, 24/32; Ebü’t-Tayyib el-Azîmâbâdî, Avnu'l-ma'bûd, (Beyrut: Dârü'l-Kütübi'l-İlmiyye, 1415), $6 / 34$.

${ }^{4}$ en-Nisâ, $4 / 21$.

${ }^{5}$ el-A'râf, 7/80-81; er-Ra'd, 13/38.

${ }^{6}$ Nikâh tarifleri için bk. Sâvî, Ebü'l-Abbas, Bulğatu's-sâlik li akrabi'l-mesâlik, (b.y.: Dârü'l-Meârif, ts.), 2/332; Hatîb eşŞirbînî, Muğni'l-muhtâc, (b.y.: Dârü'l-Kütübi'l-İlmiyye, 1994), 4/200; İbn Âbidîn, Muhammed Emîn, Reddü'l-muhtâr 'ale'd-Dürri'l-Muhtâr, (Beyrut: Dârü'l-Fikr, 1992), 3/3.
}

${ }^{7}$ Bk. Atar, "Nikâh", 33/113. 
sistemlerinde mevcuttur. Ne var ki sınırlarının dar veya geniş tutulması, bu sistemlerin oturduğu temel inanca, felsefeye, sistemin insan fitratı ve tabiatı ile olan ilişkisine, aileye verdiği öneme ve fuhuş anlayışına bağlı olarak değişkenlik arz edebilmektedir. İslâm'a göre aile, toplumun çekirdeğini oluşturduğu için ailenin ilgi ve dayanışma açısından geniş tutulması öngörülmüştür. $\mathrm{Bu}$ geniş aile çerçevesinde bazı fertlerin birbirleri ile olan ilişki ve birlikteliği daha fazla olacaktır. Farklı cinsten iki bireyin muhtelif durumlarda bir arada olmaları şehvet içgüdüsünü harekete geçirip meşru olmayan cinsî münasebetlerin meydana gelmesine sebep olabileceğinden bu olumsuz durumu engellemek için aile fertlerinin birlikteliğini sınırlamak yerine cinsî münasebetin evlenmek suretiyle olması dahi yasaklanmıştır. Böylece tarafların birbirlerine, geleceğe yönelik, muhtemel karı-koca olarak bakmaları ihtimali dahi ortadan kaldırılmıştır. ${ }^{8}$ İslâm'da mevzunun böyle titiz bir tarzda ele alınmasının sebebi, öncesinde insanlık onur ve haysiyeti ile bağdaşmayan birçok birliktelik ve nikâh türlerinin bulunmasıdır. Bu çalışmada mezkûr hususlar arasında özel olarak nikâhu'l-makt konusu üzerinde durulacaksa da birer sosyal hastalık mesabesinde olan diğer gayrimeşru nikâh ve birliktelik türlerine de temas edilecektir.

\section{Câhiliye Dönemi Nikâh Türleri ve Gayrimeşru Birliktelikler}

\subsection{Nikâh Türleri}

Özel anlamıyla Arapların İslâmiyet'ten önceki dinî ve sosyal hayat anlayışlarına karşıllk gelen câhiliye kavramı, genel olarak fert ve toplumların günah ve isyanlarını ifade eder. İslâmi dönemde ortaya çıkan bu kavram, ayet ${ }^{9}$ ve hadislerde ${ }^{10}$ Arapların İslâm'dan önceki inanç, tutum ve davranışlarını İslâmi dönemdekinden ayırt etmek için kullanılmıştır. ${ }^{11}$

Tarih, tefsir ve hadis kitaplarındaki verilerden ${ }^{12}$ de anlaşılacağı üzere câhiliye dönemindeki insanların nikâh/zevâc örfünde tek bir usûl söz konusu değildi. Bilakis mekânın, sosyal ve ekonomik konumun değişmesiyle nikâh türleri de değişkenlik göstermekteydi. Bu nikâh türlerinden bazıları hakkında günümüze kadar bazı malumatlar iletilmiștir. Tabi bu nikâh türlerinin sadece câhiliye Araplarına has bir durum olmayıp o dönemdeki muhtelif milletler tarafından da icra edildiğini burada belirtmek gerekir. ${ }^{13}$ İslâm temiz bir neslin sabit olabilmesi için; nişan, mehir ve akit ile tamamlanan bu'ûle nikâhı haricinde câhiliye dönemindeki tüm nikâh türlerini ilga etmiştir. Hz. Aişe, câhiliye dönemi Araplarda sahih nikâh, istibdâ', raht ve biğâ olmak

\footnotetext{
${ }^{8}$ Heyet, Kur'ân Yolu Türkçe Meâl ve Tefsir, (Ankara: DíB Yayınları, 2006), 2/42.

${ }^{9}$ el-Mâide, 5/50; el-Fetih, 48/2.

${ }^{10}$ Buhârî, Muhammed b. İsmail, Sahîh, (İstanbul: Çağrı Yay., 1992), "Cenâiz”, 34, 39; "Hac”, 92; "Enbiyâ", 8; Müslim b. Haccâc, Sahîh, (İstanbul: Çağrı Yay., 1992), "Îmân”, 53; 55; “Cenâiz”, 10.

${ }^{11}$ Mustafa Fayda, “Câhiliye”, Türkiye Diyanet Vakfi İslâm Ansiklopedisi (İstanbul: TDV Yayınları, 1993), 7/17.

${ }^{12}$ Detaylı bilgi için bk. Cevâd Ali, el-Mufassal fì târîhi'l-Arab kable'l-i̇slâm, (b.y.: Dârü's-Sâkî, 2001), 8/220.

${ }^{13}$ Cevâd Ali, el-Mufassal, 8/220.
} 
üzere dört tür nikâhın olduğundan bahsetmiştir. ${ }^{14}$ Kaynaklarımızda ayrıca başka nikâh türlerinden de bahsedilmiştir. Söz konusu nikâhları kısaca şu şekilde özetlemek mümkündür:

a. Nikâhu'l-Bu'ûle/Sahih Nikâh (البعولة) : Câhiliye döneminde evlilik esas olup sahih nikâh diye ifade edilebilecek bir evlilik türü vardı ki o da nikâhu'l-bu'ûle idi. ${ }^{15}$ Günümüzdeki nikâh türü olup İslâm'dan önce Araplar arasında da en yaygın/alışılmış olan bu evlilik türünde nişanlılık, mehir, icap ve kabul söz konusuydu. İslâm, meşru olan bu nikâh türünü onaylamıştır. ${ }^{16}$

b. Nikâhu'r-Raht (الرهط) : Genelde kardeş olup sayıları onu geçmeyen bir grup erkek bir kadınla, onun rızası doğrultusunda aynı zaman diliminde cinsî münasebette bulunur, ${ }^{17}$ neticede kadın hamile kaldığında bu on erkeği çağırır ve onlara: "Durumu biliyorsunuz. Çocuk doğdu." derdi. Sonra içlerinden birine: "Ey falan bu çocuk senindir." der ve artık o kişinin bunu reddetme gibi bir lüksü bulunmazdı. Çocuğun kendisinden olmadığını bilse bile babası artık bu şahıstır. ${ }^{18}$

c. Nikâhu'ş-Şiğâr/Berdel (الثغار) : Daha çok, mehir vermemek için tercih edilen bir yoldur. ${ }^{19}$ İki kişi, aynı miktarda mehir karşıllı̆ında kızlarını veya kız kardeşlerini birbirlerine evlenmek üzere vermeyi taahhüt eder ve tayin edilen mehir oranında taraflar karşılıklı borçlanmış olurlar. Takas yapılıp mehir ödemeden nikâh gerçekleşince de taraflar ödemek zorunda oldukları borçtan kurtulurdu. Zira her bir kadın diğer taraf için mehir bedeli mesabesindeydi. Mehir olmadığı için bu nikâh, şiğâr diye isimlendirilmiştir. ${ }^{20}$ Aslında burada kadına ait olan mehirden baba veya erkek kardeşler istifade etmektedirler. ${ }^{21} \mathrm{~Hz}$. Peygamber “islâm'da şiğâr yoktur." ${ }^{\text {"2 }}$ diyerek bu nikâh türünü yasaklamıştır. $^{23}$

d. Nikâhu'l-Bedel (البدل) : Adamın birinin diğerine: "Sen benim için eşini bırak/boşa, ben de senin için eşimi bırakayım/boşayayım. Sana ekstra ziyadede de bulunacağım.” demesidir ki Ahzâb Sûresi'nin

\footnotetext{
${ }^{14}$ Buhârî, "Nikâh”, 36; Ebû Dâvûd, "Talâk”, 32, 33.

${ }^{15}$ Zeynüddin er-Râzî, Muhtâru's-sıhâh, (Beyrut: el-Mektebetü'l-Asriyye, 1999), "b'al”, 37.

${ }^{16}$ Bk. Cevâd Ali, el-Mufassal, 10/205; Mahmûd Şükrî el-Alûsî, Bulûğu'l-ereb, (b.y.: y.y., ts.), 2/3.

${ }^{17}$ Buhârî, "Nikâh", 36.

${ }^{18}$ Alûsî, Bulûğu'l-ereb, 2/4; Aynî, Ebû Muhammed Bedrüddîn, 'Umdetü'l-kâri' fî Şerhi Sahîhi'l-Buhârî, (Beyrut: Dârü İhyâi't-Turâsi'l-Arabi, ts.), 20/122; Ahmed b. Muhammed el-Kastallânî, İrşâdu's-sârî, (Mısır: el-Matbaatu'l-Kübrâ, 1323), 8/49; Cevâd Ali, el-Mufassal, 10/211.

${ }^{19}$ Adnan Demircan, “Câhiliye İle İslâm Nikâh Uygulamaları Arasında Benzerlikler ve Farklılıklar”, Dinlerde Nikâh, (İstanbul: İSAV., 2012), 48.

${ }^{20}$ Tâhir b. Aşûr, Makâsıdu'ş-şerîati'l-İslâmiyye, (Katar: Vizâretu'l-Evkâf, 2004), 2/346, 573; Alûsî, Bulûğu'l-ereb, $2 / 5$.

${ }^{21}$ Serahsî, Ebû Bekir Şemsü'l-Eimme, el-Mebsût, (Beyrut: Dârü'l-Ma'rife, 1993), 5/105; Abdurrahman el-Cezîrî, el-Fikh ale'l-mezâhibi'l-erbaa, (Beyrut: Dârü'l-Kütübi'l-İlmiyye, 2003), 4/87.

${ }^{22}$ Müslim, "Nikâh", 60.

${ }^{23}$ Serahsî, Mebsût, 5/105; Abdulkerîm Zeydân, el-Medhal, (Beyrut: Müessesetü'r-Risâle, 2002), 24; Nuri Kahveci, İslâm Aile Hukuku, (İstanbul: Hikmetevi Yayınları, 2014), 22.
} 
52. ayetiyle bu uygulama yasaklanmıştır. ${ }^{24}$ Mehir olmaksızın evli olan iki erkeğin belirli bir süreliğine eşlerini değiştirmeleri şeklinde gerçekleşen bir nikâh türüdür. ${ }^{25}$

e. Nikâhu'l-Müt‘a (المتعة)) : Belirlenen bir vadeye kadar/süreli yapılan nikâhtır. Erkeğin belirli bir mal karşılı̆̆ında bir kadınla kendisiyle bir müddet kalması üzerine anlaşması, süre bitince de tarafların ayrılması şeklinde gerçekleşen nikâh türüdür. ${ }^{26}$ Câhiliye döneminde müt'anın yaygın olmadığı ve toplumun saygın kadınlarının bu tür evlilikler yapmadıkları anlaşılmaktadır. Uzun süreli yolculuklar, savaşlar ve göçebe hayatın, Arapları bu tür nikâhlara sevk ettiği ifade edilmiştir. ${ }^{27} \mathrm{~Hz}$. Ali'den gelen rivayete göre Hz. Peygamber Hayber günü müt'ayı yasaklamıştır. ${ }^{28}$

f. Nikâhu'z-Za îne (الظعينة) : Kişinin esir almış olduğu kadınla evlenme hakkı olup esir alınan kadının bundan kaçınması söz konusu değildi. Esiri olduğu şahsın mülkü olduğu için muhayyerlik hakkı bulunmadığından bu evlilik nişan ve mehir olmaksızın gerçekleşirdi. ${ }^{29}$

g. Nikâhu'ş-Şirâ' (الثراء) : Bazı Araplar bu nikâh türü ile evliliği bir tür kız satın alma faaliyeti olarak gördüğü için kızlara, kızın babasının malını arttıracak birer meta olarak bakmaktaydılar. ${ }^{30}$

ğ. Nikâhu'l-Esir (الأسر) : "Nikâhu'l-müsebbiyât/mehtûfât" olarak da bilinirdi. Araplar bir kavimle savaştıklarında o kavmin mallarını alıp erkek ve kadınlarını da esir olarak alıkoyar ve kendi aralarında paylaşırlardı. Payına kadın düşen erkekleri köle yapar, kadınları da cariye olarak kullanıp bazılarıyla evlenirlerdi. ${ }^{31}$ Mahiyeti itibariyle bu nikâh türünün, zaîne nikâhı ile eş anlamlı olduğu anlaşılmaktadır.

h. İki Kız Kardeşi Aynı Nikâhta Tutmak: Câhiliye dönemindeki bu uygulamayı İslâm yasaklanmıştır. ${ }^{32}$ Bununla birlikte, karısının ölmesi durumunda kişi, baldızı ile evlenebileceğinden iki kız kardeşle evlilik daimi değil, geçici bir evlilik engelini oluşturur. ${ }^{33}$

\footnotetext{
${ }^{24}$ Muhammed b. Ahmed el-Kurtubî, el-Câmi' li ahkâmi'l-Kur'ân, (Kâhire: Dârü'l-Kütübi'l-Misriyye, 1964), 14/220.

${ }^{25}$ Cevâd Ali, el-Mufassal, 10/209.

${ }^{26}$ Serahsî, Mebsût, 5/143-144, 152; Abdullah b. Mahmud el-Mevsılî, el-ìhtiyâr li ta'lîli'l-Muhtâr, (Kâhire: y.y., 1937), 3/89, 111; Zeylaî, Fahreddin Osman b. Ali, Tebyîn̈̈l-hakâik, (Kâhire: Matbaatü’l-Kübrâ, 1313), 2/115.

${ }^{27}$ Cevâd Ali, el-Mufassal, 537.

${ }^{28}$ Buhârî, "Nikâh", 31; Müslim, "Nikâh", 29-32. Müt'a nikâhı hakkında bk. Murat Sarıcık, "Câhiliye Nikâhı Mut'a ve Diğer Câhiliye Nikâhları”, SDÜíFD. 3 (1996), 41-53.

${ }^{29}$ Cevâd Ali, el-Mufassal, 10/218.

${ }^{30} \mathrm{Bk}$. https://www.almerja.com/reading.php?idm=71395

${ }^{31}$ Abdusselâm Termânînî, ez-Zevâc 'inde'l-Arab, (Kuveyt: y.y., 1984), 30.

${ }^{32}$ en-Nisâ, 4/23.

${ }^{33}$ Muhammed b. İdris eş-Şâfiî, el-Ümm, (Beyrut: Dârü'l-Ma'rife, 1990), 5/5, 161; M. Reşid Rızâ, Tefsîru'l-Kur'âni'lHakîm, (b.y.: y.y., 1990), 4/394; Abdulvehhâb Hallâf, Ahkâmu'l-ahvâli'ş-şahsiyye, (Kâhire: Dârü'l-Kütübi'l-Misriyye, 1938), 52.
} 
i. Çok Eşlilik (تعدد الزوجات) : Câhiliye döneminde evlilikte bir sınır bulunmadığından erkek, aynı anda birçok kadınla evli bulunabiliyordu. ${ }^{34}$ On eşe kadar vuku bulabilen bu uygulamayı İslâm dört ile sınırlandırıp ${ }^{35}$ bunun için de eşler arasında adaletin gözetilmesini şart koşmuştur. ${ }^{36}$

Son olarak Araplar arasında kızlarıyla evlenenlerin dahi olduğunu burada ifade etmek gerekir. ${ }^{37}$ Makt nikâhı ileride ele alınacağı için burada ayrıca zikredilmeyecektir. Bununla birlikte câhiliye döneminde var olduğu ifade edilen nikâh türlerinin yanı sıra muhtelif şekillerde nikâhsız birliktelikler de söz konusuydu. Kısaca bunlara değinmekte de fayda mülahaza ediyoruz. ${ }^{38}$

\subsection{Gayrimeşru (Nikâhsız) Birliktelikler}

Câhiliye Araplarında nikâh kisvesine büründürülmemiş bazı gayrimeşru birliktelik türleri daha bulunmaktadır ki bazı kaynaklarda bunlar, birer nikâh türü olarak zikredilse bile ${ }^{39}$ bunları nikâh olarak isimlendirmek uygun görünmemektedir. Söz konusu birliktelikleri şu şekilde özetlemek mümkündür:

a. Zina (الزنا) : Zina fiili İslâm'da bir suç olarak tanımlanıp bu fiile cezai müeyyide bağlanmıştır. ${ }^{40} \mathrm{Bu}$ kavram nikâhsız gayrimeşru ilişkileri ifade ettiğinden aslında câhiliye dönemindeki tüm gayrimeşru ilişkileri kapsamaktadır. Zina fiili, muhtelif şekillerde gerçekleştiği için bu ilişkiler farklı isimlerle anılmıştır.

b. Hidn/Mühâdene (المخادنة) : Erkeğin bir kadını gizli dost edinmesi anlamına gelen bu birliktelik, Kur'ân'da yasaklanmıştır. ${ }^{41}$ Hür ve asil kadınların kaçındığı bu tür birliktelikler câhiliye döneminde yaygın değildi. ${ }^{42}$

c. Mudâmide (المضامدة) : Evli bir kadının bir veya birden fazla kişi ile muâşerette bulunmasına/dost hayatı yaşamasına denirdi. Bazı amillerin kadını böyle bir fiile sevk ettiği ifade edilmektedir. ${ }^{43}$

\footnotetext{
${ }^{34}$ Zeydân, Medhâl, 25.

${ }^{35}$ en-Nisâ, $4 / 3$.

${ }^{36}$ en-Nisâ, 4/129.

${ }^{37}$ Kurtubî, el-Câmi', 5/104.

${ }^{38}$ M. Âkif Aydın, “Aile”, Türkiye Diyanet Vakfi İslâm Ansiklopedisi (İstanbul: TDV Yayınları, 1989), 2/198; Saffet Köse, "Câhiliye Arap Toplumunda Kocaların Hanımlarına Yaptıkları Bazı Haksızlıklar ve İslâm'ın Getirdiği Hukukî Düzenlemeler”, Mehir (1999), 8.

${ }^{39}$ Örneğin bk. Alûsî, Bulû̆ğu'l-ereb, 2/4-5.

${ }^{40}$ en-Nûr, 24/2.

${ }^{41}$ el-Mâide, $5 / 5$.

${ }^{42}$ Bk. Cevâd Ali, Mufassal, 5/545; Sarıcık, “Câhiliye Nikâhı Mut'a ve Diğer Câhiliye Nikâhları”, 63-70.
} 
d. İstibdâ' (استبضاع) : Kadının bud'undan istifade etmeyi ifade eder. Bud', evlilikten kinaye yolu ile ferc anlamına gelir. ${ }^{44}$ Erkek, çocuğunun daha asil, zeki ve sağlıklı olabilmesi için karısını hayızdan temizlendikten sonra bir erkeğe gönderip ondan çocuk sahibi olmasını ister, hamile olduğu anlaşılıncaya kadar da karısına yaklaşmazd. ${ }^{45}$

e. Biğâ'/Serbest Cinsel İlişkiler (البغاء)) : Kadınların zina yapmasına denir. Biğâ'yı mudâmide ve muhâdine türü ilişkilerden ayıran, karşıllı̆̆ında kadına bir ücretin ödeniyor olmasıdır. ${ }^{46}$ Genelev türü yerlerde fahişe olup herkesin kendileriyle cinsî münasebette bulunduğu ve bunu belirtmek için kapılarında bayrak asılı bulunan kadınlardan biri çocuk doğurduğunda kendisiyle münasebette bulunan tüm erkekleri toplar ve bir kâif ${ }^{47}$ marifetiyle çocuğun babasının kim olduğu tayin edilirdi. Böylece o kişi çocuğun babası olarak tanınırdı. ${ }^{48}$

Kaynaklarda zikri geçen yukarıdaki câhiliye nikâh ve birlikteliklerin çoğunu İslâm, zina olarak değerlendirmiştir. Bu beraberliklerin mağdurları, çoğunlukla sahiplerinin cinsel sömürüsüne maruz kalan cariyelerdir. ${ }^{49}$ İslâm'dan önce Araplar anne, kız, kız kardeş, hala ve teyze gibi bazı akrabalar ile evliliği yasaklayıp ${ }^{50}$ evlat edinmeyi de bir evlilik engeli olarak kabul ederlerdi. ${ }^{51}$ İslâm evlatlık edinmeyi kaldırmak suretiyle böyle bir evlilik engeline de son vermiştir. ${ }^{52}$ İbn Abbas Arapların akrabalarla evliliklerinin sadece üvey anne ile evlenme ve iki kız kardeşi aynı nikâh altında bulundurma şeklinde vuku bulduğunu ifade etmektedir. ${ }^{53}$ Fakat bu yeterli değildi. Zira bu dönemde uygulanan nikâh türleri, toplum katında bir kadınla bir erkeğin birlikte yaşamasını meşrulaştıran beraberlikler olarak görülse de İslâm bunların bazılarını reddetmiş, bazılarını tadil etmiş, bir kısmını da onaylamıştır. Tabi bu nikâh türlerinin tümü o dönemde genel kabul görmüş değildi. ${ }^{54}$ Gayrimeşru ve gayri ahlaki birliktelikler ve bunun neticesinde gerçekleşen nikâhların

\footnotetext{
${ }^{43}$ Bk. İbn Manzûr, Lisânü'l-'Arab, “dmd”, 3/266; Zebîdî, Tâcu'l-arûs, “ed-damd”, 8/314; Ebû Bekr el-Ezdî, Cemheretu'lluğa, thk. R. Münir Ba'lebekî, (Beyrut: Dârü'l-İlm, 1987), “ddm”, 2/659; Termânînî, ez-Zevâc inde’l-Arab, 19-20.

${ }^{44}$ Rağıp el-İsfehânî, el-Müfredât fi ğarîbi'l-Kur'ân, (Beyrut: Dârü'l-Kalem, 1412), 129; İbn Manzûr, Lisânü'l-'Arab, "bda”, 8/14; Alûsî, Bulûğu'l-ereb, 2/4.

${ }^{45}$ Mecduddîn İbnü'l-Esîr, en-Nihâye fí ğarîbi'l-hadîs, (Beyrut: el-Mektebü'l-İlmiyye, 1979), 1/133; Aynî, Umdetu'l-Kâri', 20/121-122; Buhârî, "Nikâh", 36.

${ }^{46}$ Termânînî, ez-Zevâc inde’l-Arab, 22-23.

${ }^{47}$ Kıyâfe: "İki kişinin organlarındaki benzerlikten aralarında kan bağı bulunduğunu ve karakterlerinin nasıl olduğunu tespite yarayan tahminî bilgi." Bk. M. Serhan Tayşi, "Kıyâfe”, Türkiye Diyanet Vakfi İslâm Ansiklopedisi (Ankara: TDV Yayınları, 2002), 25/508.

${ }^{48}$ Alûsî, Bulûğu'l-ereb, 2/4-5; Cevâd Ali, el-Mufassal, 10/212.

${ }^{49}$ Demircan, "Câhiliye İle İslâm Nikâh Uygulamaları", 49.

${ }^{50}$ Neşet Çağatay, İslâm'dan Önce Arap Tarihi ve Câhiliye Çağı, (Ankara: Ankara ÜİF. Yayınları, 1957), 124.

${ }^{51}$ Zeydân, Medhal, 25.

${ }^{52}$ el-Ahzâb, 33/4.

${ }^{53}$ Ebû Hayyân el-Endülûsî, el-Bahru'l-muhît, thk. M. Cemil, (Beyrut: Dârü'l-Fikr, 1420), 3/575.

${ }^{54}$ Demircan, "Câhiliye İle İslâm Nikâh Uygulamaları", 35.
} 
herkesin onayından geçmediği ve toplumun sadece bir kısmı tarafından icra edildiği anlaşılmaktadır. Ayrıca İslâm'dan önce Araplarda evlilik, herhangi bir şekil şartına veya merasime tabi değildi. Fakat yine de velime denilen düğün yemeği vermek genel bir uygulama olarak görünmektedir. ${ }^{55}$

\section{Sürekli Bir Evlilik Engeli Olarak Makt Nikâhı}

İslâm hukukunda evlilik engelleri iki başlık halinde ele alınmıştır. Bunlardan ilki olan müebbed (mutlak/daimi) evlenme engelleri, Nisâ Sûresi'nin 22, 23 ve 24. ayetleri ile düzenlenmiş; kan hısımlığı, sıhri hısımlık ve süt hısımlığı sürekli evlenme engeli kabul edilmiştir. İkincisi ise muvakkat (nisbî/geçici) evlilik engelleridir. ${ }^{56} \mathrm{Bu}$ taksimde nikâhu'l-makt, daimi evlilik engellerinden olan sıhri hısımlık başlığı altında ele alınmaktadır. Sıhri hısımlıktan kaynaklanan evlilik yasağına "hürmet-i musâhere" denilmektedir. Sıhri hısımlı, evlenmeden kaynaklanan hısımlık sebebiyle kendileriyle evlenilmesi yasaklananlar demektir. Kur'ân'da bu anlamda üvey anneler, kayınvalideler, gerdeğe girilen hanımların üvey kızları ve gelinler ile yapılacak nikâhlar haram kılınmıştır. ${ }^{57}$

“ََ “mekate” fiilinin masdarı “mektun” olup sözlükte iğrenme ve aşırı buğz (kin/nefret) gibi anlamlara gelir. Makt, işlenen çirkin bir işe duyulan nefreti ifade ederken bu kökten türeyen مَقِيتُ “mekît” nefret edilen, iğrenç kişi demektir. ${ }^{58}$ Kur'ân'da altı yerde zikri geçen bu kelime sözlük anlamında kullanılmıştır. ${ }^{59}$ Terim olarak da kişinin, babasının ölümünden sonra üvey annesi ile nikâhlanmasını ifade eden bu nikâh yasaklanmıştır. Cenâb-ı Hak hiçbir ümmetin böyle çirkin bir fiilde bulunmasına müsaade etmemiş ve buna ruhsat tanımamıştır. Murûet sahipleri için nefret duyulacak bir durum söz konusu olduğundan "mkt" ifadesi kullanılmış ve bu metodu uygun görüp yapanların yolu da "kötü yol" olarak isimlendirilmiştir. ${ }^{60}$ Câhiliye döneminde çirkin olan bu fiili yapanlar olduğu gibi böyle yapanları kınayıp nefret edenler de vardı. Bu çirkin fiilde bulunan kişiye "el-mektî / المَقْتئُ ", doğan çocuğa da "el-mektâ" denilmiştir. Sahibi nefrete uğrayacağ1 için ayette bu nikâh "makt / مقت olarak isimlendirmiş ve sanki şöyle denilmek istenmiştir: Bu, çirkinlikte son nokta olup Allah'ın dininde açık bir kötülük/fahişeliktir. ${ }^{61}$ Makt nikâhının Araplara

\footnotetext{
${ }^{55}$ Aydın, "Aile", 2/198.

${ }^{56}$ Bk. Hallâf, Ahkâmu'l-ahvâli'ş-şahsiyye, 46-57.

${ }^{57}$ en-Nisâ, 4/23.

${ }^{58}$ İbn Manzûr, Lisânü'l-'Arab, “mkt”, 2/90; Zebîdî, Tâcu'l-arûs, “mkt”, 5/95; Celâleddin es-Suyûtî, Tefsîru'l-Celâleyn, (Kâhire: Dârü'l-Hadîs, ts.), 103.

${ }^{59}$ Bk. el-Fâtır, 35/39; el-Mü'min, 40/10, 35; es-Saf, 61/3.

${ }^{60}$ Nâsiruddin Ebû Saîd el-Beydâvî, Envâru't-tenzîl, (Beyrut: y.y., 1418), 2/67.

${ }^{61}$ İbn Manzûr, Lisânül-'Arab, "mkt”, 2/90; Kurtubî, el-Câmi', 5/103-104; Ebü'l-Kâsım ez-Zemahşerî, el-Keşşâf, (Beyrut: Dârü'l-Kütübi'l-Arabî, 1407), 1/492-493.
} 
Farslardan geçtiği ifade edilmektedir. ${ }^{62}$ Önceleri Arapların bu nikâhtan iğrendikleri için bu nikâha "nikâhu'l-makt", ${ }^{3}$ bu nikâhtan doğan çocuğa ya da üvey annesi ile evlenen kişiye "ed-dayzen / "الضيزن" demişlerdir. ${ }^{64}$ Aslında "dayzen" şeklindeki uygulamada oğlun, üvey annesini alıp onun başkasıyla evlenmesine engel olma hakkı varken üvey annesinin bir mal vermek suretiyle söz konusu üvey oğlunu razı edip kurtulması söz konusudur. ${ }^{65}$ Sunulan bu mala razı olan varise "dayzen" denilirdi. Ölenin oğlunun üvey annesiyle evlenmesi durumunda doğacak çocukları ise onun kardeşleri olarak kabul edilirdi. ${ }^{66}$ Bu yüzden makt nikâhı, "nikâhu'd-dayzen" diye de bilinir. ${ }^{67}$ Üvey annesiyle evlendikten sonra bu evlilik, evladın babasından nefret etmesine sebep olur. Zira genelde bir kadınla evlenen biri, o kadının ilk kocasından nefret eder. Bu yüzden Hz. Peygamber'in eşleri, yani müminlerin anneleri ile evlenmek de müminlere haram kilınmıştır. Zira eşleri müminlerin anneleri olunca Hz. Peygamber de müminlerin babası konumunda olmaktadır. ${ }^{68}$ Söz konusu nikâhın "nefret evliliği” olarak adlandırılmasından, bu nikâhın hem evlat hem de üvey anne için arzu edilebilir bir durum olmadığı, fakat toplumsal baskı altında böyle bir sıkıntıya maruz kaldıkları anlaşılmaktadır.

Makt nikâhının câhiliye döneminde normal karşılanmasının şöyle bir arka planı olabilir: $\mathrm{Bu}$ dönemde yapılan evliliklerde kadınla erkeği birbirine bağlayan nikâh, dini bir mahiyet arz etmediği için kadın, ancak çocuk doğurduktan sonra aileden sayılırdı. Bu yüzden çocuk doğurmadan ölen bir kadın için kocasına taziyeye gidilmezdi. Çocuksuz olan bir kadın diyet ödemeye mahkûm kaldığında bu diyeti kocası değil, kadının mensubu bulunduğu aile topluluğu verirdi. Araplar, sadece bu aile topluluğu akrabalı̆̆ına önem verdiklerinden evlenme yolu ile ortaya çıkan akrabalığın önemi yoktu; bu sebeple bir baba öldüğünde oğulları, üvey anneleriyle evlenebilmekteydi. ${ }^{69}$ Buradan da makt nikâhının konusunun, çocuğu olmayan üvey anneler olduğu anlaşılmaktadır.

\footnotetext{
${ }^{62}$ Zebîdî, Tâcu'l-arûs, "mkt”, 5/95; Termânînî, ez-Zevâc 'inde'l-Arab, 26.

و الفارسية فيهم غير منكرة - فكلهم لأبيهح ضيزن سلف :

${ }^{64}$ Kurtubî, el-Câmi', 5/105; Muhammed b. Ali eş-Şevkânî, Fethü'l-kadîr, (Beyrut: Dârü İbni Kesîr, 1414), 1/508; Muhammed b. Habîb Ebû Ca'fer, el-Muhabber, (Beyrut: Dârü'l-Âfâki'l-Cedîde, ts.), 325; Ebü'l-Fidâ İmâduddin, elMuhtasar fî ahbâri'l-beșer, (Mısır: el-Matbaatu'l-Hüseyniyye, ts.), 1/99; İbnu'l-Verdî el-Ma'rî, Târîhu İbni'l-Verdî, (Beyrut: Dârü'l-Kütubi'l-i̇lmiyye, 1996), 1/84; Çağatay, İslâm'dan Önce Arap Tarihi, 124.

${ }^{65}$ Cevâd Ali, el-Mufassal, 5/535.

${ }^{66}$ Termânînî, ez-Zevâc inde'l-Arab, 26.

${ }^{67}$ Muhammed b. Cerîr et-Taberî, Câmiu'l-beyân fî te’ vîli'l-Kur'ân, (b.y.: Müessesetü'r-Risâle, 2000), 4/207; Şihâbuddîn el-Alûsî, Rûhu'l-meânî, thk. A. Abdülbârî Atiyye, (Beyrut: Dârü'l-Kütübi'l-İlmiyye, 1415), 4/245; Reşid Rizâ, Tefsîru'lKur'âni'l-Hakîm, 4/452; Cevâd Ali, el-Mufassal, 10/206.

${ }^{68}$ Ahmed b. Hanbel, Müsned, 4/229; Ebü'l-Fidâ İbn Kesîr, Tefsir-u'l-Kur'âni'l-Azîm, (Beyrut: Dârü'l-Kütübi'l-İlmiyye, 1419), 2/215.

${ }^{69}$ Çağatay, İslâm'dan Önce Arap Tarihi, 116-117.
} 
Câhiliye adetlerine göre biri ölür, karısı sağ kalır, ölenin bir başka kadından oğlu da bulunursa bu oğul/büyük oğul, üvey anne istese de istemese de mehir vermeden onunla evlenebilir veya oğul kendi istediği bir erkekle üvey annesini evlendirip mehrinin kendisine verilmesini şart koşabilir yahut sevmediği ve ilgi göstermediği halde üvey annesini boşamaz ölünceye kadar hiç evlendirmez, ölünce mirasına konar ve böylece ona zorla varis olurdu. Eğer oğul, babasının ölümünden sonra üvey anasıyla evlenmek istemezse bu hak belirli bir sırayla diğer oğullara ve asabe akrabalara geçerdi. Ölenin karısıyla evlenecek başka eşinden oğlu yoksa ya kadın çabuk davranarak kaçıp baba tarafına sığınmak suretiyle kurtulur ya da ölenin erkek yakınlarından biri elini çabuk tutup kadının üzerine elbisesini atarak ilanda bulunur ve kadın böylece nişanlanmış sayılırdı. Oğul küçükse büyüyünceye kadar kadın onun için bekletilir, büyüdüğünde de o kadını dilerse alır, dilerse almazdı. ${ }^{70}$ Büyük oğulun üvey anne ile evlenmeye ihtiyacı yoksa diğer kardeşlerden biri, yeni bir mehirle üvey annesi ile evlenirdi. Tarihçiler bu yeni mehirden bahsetmemektedir. Muhammed b. Hubeyb bu bilgiye dikkatleri çekmiştir. Şöyle ki büyük oğul yasal hakkından vazgeçtiği için bu mehir, onu razı etmek adına verilirdi. ${ }^{71}$

Allah Teâla, bu menfur evliliği kaldırıp müstakil bir tarzda şöyle yasaklamıştır: "Bir de babalarınızın nikâhladığı kadınları kendinize nikâhlamayın. Câhiliye devrinde yaptıklarınız affedilmiştir. Şüphe yok ki o, pek çirkin bir evliliktir. Allah'in buğzuna sebep olan o ne fena bir adettir."72 ve "Ey iman edenler! Kadınlara zorla varis olmanız size helal değildir. Mehir olarak verdiğiniz malların birazın kurtaracaksınız diye onları tazyik etmeniz, mal karşllğı boşamak istemeniz de helal olmaz." "3 Malı için değil de kadının bizzat kendisi ile evlenmenin amaç olarak değerlendirilmesi durumunda ayete "Kadınları zorla miras olarak almayın." şeklinde meal vermek daha uygun iken, amacın kadınla malı için evlenmek olduğu düşünüldüğünde "Kadınlara zorla varis olmanız size helal değildir." şeklinde meal verilmesi daha uygun olacaktır. ${ }^{74}$ "Babalarınızın nikâhladığı kadınlarla evlenmeyin." ayeti nazil oluncaya kadar "Ey iman edenler! Kadınlara zorla varis olmanız size helal değildir." ayeti gereği insanlar babalarının eşleri ile onların rızası dâhilinde evlenmekteydi. Son ayet nazil olunca her halükarda babaların eşleri ile evlenmek haram kılınmış oldu. ${ }^{75}$

Üvey anneler ile evlenmeyi helal gören Araplar iki gruptu. Birinci gruba göre kişi babasının mallarına varis olduğu gibi rızasına bakılmaksızın üvey annesini de miras olarak alıp yeni bir nikâh olmadan onunla cinsî münasebette bulunabileceği kanaatinde olduğundan "Kadınlara zorla varis

\footnotetext{
${ }^{70}$ Buhârî, “Tefsir”, 4/6; Ahmed b. Ali el-Cessâs, Ahkâmu'l-Kur'ân, (Beyrut: Dârü İhyâi't-Turâsi'l-Arabî, 1405), 3/49-50; Reşid Rizâ, Tefsîru'l-Kur'âni'l-Hakîm, 4/464; Zeydân, Medhal, 24; Aydın, “Aile”, 2/198.

${ }^{71}$ Taberî, Câmiu'l-beyân, 4/208, 217; İbn Habîb, el-Muhabber, 325-326; Cevâd Ali, el-Mufassal, 207-208.

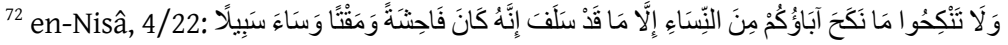

${ }^{73}$ en-Nisâ, 4/19.

${ }^{74}$ Bk. Heyet, Kur'ân Yolu, 2/36; Çağatay, İslâm'dan Önce Arap Tarihi, 124.

${ }^{75}$ Kurtubî, el-Câmi', 5/103.
} 
olmanız helal olmaz." ayeti nazil olmuştur. Diğer gruba göre ise üvey anne, ancak yeni bir nikâh ile helal olabilmektedir ki bu hususta da "Babalarınızın nikâhlları ile evlenmeyin." ayeti inmiştir. ifadesinden kasit haram olduğu öğrenildikten sonra üvey anneler ile ayrılma durumunda muahezenin söz konusu olmayacağıdır. Tahrim ayeti ile birlikte daha önce makt nikâhı yapanların nikâhları iptal olmakta ve tarafların ayrılmaları gerekmektedir. ${ }^{76}$

\section{Makt Nikâhı'nın Fıkhi Boyutu}

Özel bir tarzda makt nikâhını haram kılan Nisâ Sûresi'nin 22. ayeti, bazı açılardan İslâm hukukçularının ilgi alanını oluşturmuştur. Örneğin ilgili ayette nikâh kelimesinin ne anlama geldiği, sırf nikâh akdinin ya da babanın zina yaptığı kadınların haramlık oluşturup oluşturmadığı ve böyle bir nikâhın nasıl bir ceza gerektirdiği gibi hususlar bunlardandır. Şimdi bu hususları açıklayacağız.

\subsection{Hanefîlerin Görüşü}

Hanefîlere göre mezkûr ayetteki nikâh kelimesi müşterek bir lafiz olup hem nikâh/akit hem de vat'/cinsî münasebet anlamına gelir. Ne var ki hakikatte vat'ı ifade ettiğinden kapsamına babanın sahih nikâhı altındaki kadınların yanı sıra cinsî münasebette bulunduğu kadınlar da girer. Cinsî münasebet akit ile mümkün olduğu için nikâh diye ifade edilmiştir. ${ }^{77}$ Bu yüzden nikâha, bu anlamın verilmesi daha uygundur. Böylece babanın münasebette bulunduğu cariyeler de oğula haram olacaktır. $\mathrm{Bu}$ bağlamda ayet, babaların cinsi münasebette bulunduğu kişilerle cinsi münasebette bulunulmamasını ifade etmektedir. Nikâh da zina da bu kapsama girer. Bir kadınla zina yapıldığında o kadının annesi ve kızının da haram olacağını bildiren rivayetler de bunu göstermektedir. ${ }^{78}$ Bir kadına dokunmak ve onun avret mahalline bakmak da aynı hükme tabi olup ihtiyaten hürmet-i musâhare olarak kabul edilmiştir. ${ }^{79}$ Hanefî mezhebine göre evlenilmesi haram olan biriyle yapılmış olsa bile zina, hürmet-i musâhareyi doğurur. ${ }^{80}$ Hanefîlere göre Nisâ, 22. ayetin umumi manası alınır ve helal olan cinsî münasebetlere verilen haramlık hükmü, haram yolla oluşan cinsî münasebetlere de verilir. Zira her ikisinde de istimtâ‘/faydalanma söz konusudur. ${ }^{81}$ Zifaf olsun veya olmasın fark etmez babanın nikâhı altındakilerle evlenmek oğul için haramdır. ${ }^{82}$

\footnotetext{
${ }^{76}$ Serahsî, Mebsût, 4/198.

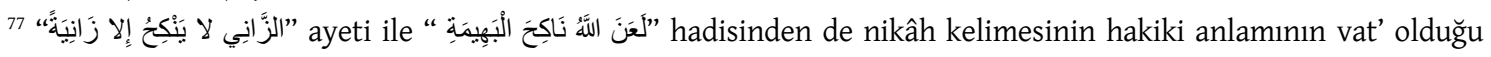
anlaşılmaktadır. Bk. Ebubekir b. Ali ez-Zebîdî, el-Cevheretu'n-neyyire, (b.y.: el-Matbaatu'l-Hayriyye, 1322), 2/2. 
Evlenilmesi haram olan biriyle evlenip onunla cinsî münasebette bulunan bir şahsa, bu kadının kendisine haram olduğunu bilsin veya bilmesin fark etmez Ebû Hanîfe'ye (v. 150/767) göre had değil, ta'zîr cezası uygulanır. ${ }^{83}$ İmâmeyn'e ${ }^{84}$ göre ise biliyorsa, yaptığı şey zina olduğundan kendisine had uygulanır. Zira ayetteki "fâhişe" kelimesi zina anlamına gelmektedir. Ebû Hanîfe'ye göre batıl bir akit olsa da nikâh akdi şüphesi, haddi düşürür. Nikâh kelimesi hem akdi hem de vat'1 ifade ettiğinden her iki durumda da haramlık oluşur. Zira böyle bir nikâh, nesli bozacaktır. ${ }^{85}$ Sırf sahih nikâhla haramlık oluşurken nikâhın fasit olması durumunda yalnız akit ile haramlık oluşmaz. Dolayısıyla fasit nikâh akdinde haramlık ancak babanın cinsî münasebette bulunmuş olması, şehvetle kadının avret mahalline bakması veya dokunması ile mümkündür. Nesep açısından haram olanlar süt yoluyla da haram olacağından babanın neseben öz veya sütbaba olmasi arasinda fark yoktur. ${ }^{86}$

\subsection{Mâlikîlerin Görüşü}

Mâlikî hukukçulara göre nikâhın hakiki manası akit, mecazi manası ise cinsî münasebettir. Sırf akit ile haramlık oluşacağından zifaf olsun veya olmasın fark etmez üvey anne, oğula haram olur. Fasit nikâh da haramlık oluşturur, fakat dokunmak böyle bir haramlık doğurmaz. Yukarı doğru nesep ve süt yoluyla dedeler de haram olur. ${ }^{87}$

\section{3. Şâfiîlerin Görüşü}

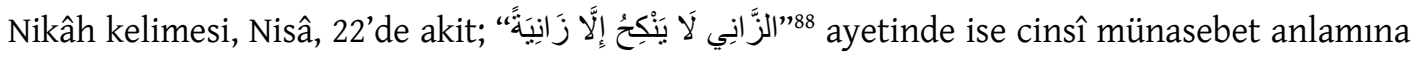
gelmektedir. ${ }^{89}$ Baba, zifafa girmiş bulunsun veya bulunmasın fark etmez evlendiği kadınlar, oğluna/fürûuna haram olur. ${ }^{90} \mathrm{Bu}$ anlamda ilgili ayetin manası "Babalarınızın nikâh akdi yaptiğı kadınlarla evlenmeyin.” olacağından oğul, babasının zina yaptığı kadınlar ile evlenilebilir. Zira vat',

\footnotetext{
${ }^{83}$ İbnü'l-Hümâm, Kemâlüddîn, Fethü'l-kadîr, (b.y.: Dârü'l-Fikr, ts.), 5/246; Zeylaî, Tebyîn, 3/175; Ebû Ca'fer et-Tahâvî Muhtasaru ihtilâfi'l-ulemâ, (Beyrut: Dârü'l-Beşâiri'l-İslâmiyye, 1417), 3/296.

${ }^{84}$ Ebû Yûsuf ve İmam Muhammed'e göre Mahremlerle evlenenlere had cezası uygulamak zorunludur. Ta'zîr ise bunun dişındaki batıl evlilikler için söz konusudur. Bk. İbnü'l-Hümâm, Fethü'l-kadîr, 5/246; Ebü'l-Hasen Alî b. Muhammed b. Habîb el-Basrî el-Mâverdî, Hâvi'l-kebîr, (Beyrut: Dârü'l-Kütübi'l-i̇lmiyye, 1999), 9/215.

${ }^{85}$ Serahsî, Mebsût, 9/85; Kâsânî, Alâüddîn Ebû Bekr b. Mes‘ûd, Bedâiu's-sanâi', (Beyrut: Dârü'l-Kütübi'l-ílmiyye, 1986), $2 / 260$.

${ }^{86}$ Zebîdî, Cevheretu'n-neyyire, 2/3-4.

${ }^{87}$ Adevî, Ebü'l-Hasen Ali b. Ahmed, Hâsşiyetü'l-'Adevî, (Beyrut: Dârü'l-Fikr, 1994), 2/59; Ahmed b. Ğânim el-Ezherî, elFevâkihu'd-dîvânî, (b.y.: Dârü'l-Fikr, 1995), 2/18; İbn Rüşd el-Kurtubî, el-Mukaddimâtü'l-mumehhidât, (Beyrut: Dârü'lĞarbi'l-İslâmî, 1988), 1/458.

${ }^{88}$ en-Nûr, $24 / 3$.

${ }^{89}$ Ebû Bekr b. Muhammed Takiyyuddîn, Kifâyetü'l-ahyâr, (Dımaşk: Dârü'l-Hayr, 1994), 1/410.

${ }^{90}$ Şâfiî, Ümm, 5/26.
} 
nikâh diye isimlendirilmez. ${ }^{11}$ Dolayısıyla babanın zina yaptığı kadınlarla evlenmek, Hanefîlere göre hürmet-i musâhare oluştururken şâfiîlere göre oluşturmaz. Şâfiîler nikâhı hakiki anlamda akit olarak algıladığından oğlun, babasının zina yaptığı kadınla evlenmesi mümkün görülmüştür. Hanefîlere göre ise nikâh kelimesi hakiki anlamda vat'i ifade ettiği için helal veya haram tüm cinsî münasebetleri kapsar. ${ }^{92}$ Şaffîlere göre musâhare bir nimet olup bu nimete haram yollarla ulaşılamaz. ${ }^{93}$

Söz konusu ayette, üvey anne ile evlenmenin zinadan daha kötü bir fiil olduğu

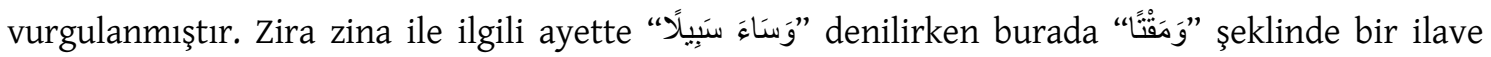
yapılmıştır. Dolayısıyla makt nikâhının faili cezalandırılmada daha evleviyetlidir. ${ }^{94}$ Ayette

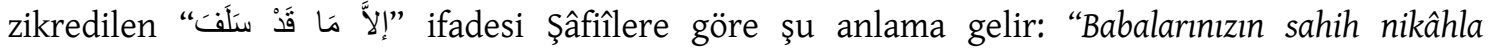
nikâhladıkları ile nikâhlanmayın. Bundan önce zina yaptıkları ile evlenenler hariç. Bunlarla nikâh yapmak helaldir. Zira bu kadınlar babalarınızın (nikâhlı) eşleri değildir. ${ }^{, 95}$

İmam Şâfiî (v. 204/820), gerdeğe girdikten sonra kaynanasıyla bilerek evlenen biri hakkında her ikisine de had uygulanacağını, zira her ikisinin de nikâh adı altında zina yaptığını ifade etmiştir. İmam şâfiî ve Beyhakî (v. 458/1066) rivayetlerde ölümüne ve malının alınmasına hükmedilen şahsın, haramı helalleştirdiği ve dolayısıyla mürted veya muharip olduğu yönündeki görüşleri değişik açılardan reddetmektedir. Hadislerde zina ve recm ifadeleri geçmediği gibi ilgili şahsın haramı helal kılıp mürted olduğu da zikredilmemekte ve şahsın irtidâtı hususunda icmâ da bulunmamaktadır. ${ }^{96}$ Netice itibariyle Beyhakî şunları ifade etmektedir: Bazı âlimler mezkûr hadisin zahirinden yola çıarak böyle birinin işlediği haramın çirkinliğinden ötürü her halükarda öldürülmesi gerektiğini ifade etmişlerdir. Bazıları da bu olayın zina ile ilgili hadleri düzenleyen ayetlerin inmesinden ve Rasûlullah'ın zina yapan evli kişilerin recmedilmesi yönündeki hükmünden önce olduğunu belirtmişlerdir. Ayet nazil olunca da durum bu şekilde değişmiştir. Bu görüşte olanlara göre öldürmenin şekli neshedilmiş, boynunu vurma yerine recm cezası getirilmiş, fakat zina yapanın öldürülmesi yönündeki hüküm neshedilmeyip hükmü baki kalmıştır.

Hattâbî (v. 388/998) bu hususta şöyle demiştir: Bu nikâhın şüphe oluşturup haddi düşüreceği iddiası çok zayıftır. Şüphe bazı yönlerden helale benzeyen hususlarda olur ki mahrem olanların

\footnotetext{
${ }^{91}$ Remlî, Şemsuddin Muhammed, Nihâyetu'l-muhtâc, (Beyrut: Dârü'l-Fikr, 1984), 6/177.

${ }^{92}$ İbn Nüceym, Zeynüddîn, el-Bahru'r-Râik Şerhü Kenzi'd-Dekâik, (b.y.: Dârü'l-Kitâbi'l-İslâmî, ts.), 3/82.

${ }^{93}$ Muhammed el-Ferrâ' el-Begavî, et-Tehzîb fî fikhi'l-İmâm eş-Şâfî̀, thk. Âdil Ahmed Abdulmevcûd-Alî Muhammed Muavvez, (Beyrut: Dârü'l-Kütübi'l-İlmiyye, 1997), 5/365; Ebü'l-Kāsım Abdülkerîm b. Muhammed b. Abdilkerîm erRâfiî el-Kazvînî, el-Azîz şerhu'l-Vecîz, thk. Ali Muhammed İvez-Âdil Ahmed Abdulmevcûd, (Beyrut: Dârü'l-Kütübi'lİlmiyye 1997), 8/36.

${ }^{94}$ Ebü'l-Bekâ Kemâlüddîn ed-Demîrî, en-Necmu'l-vehhâc fi şerhi'l-Minhâc, (b.y.: Dârü'l-Minhâc, 2004), 9/110.

${ }^{95}$ Mâverdî, Hâvi'l-kebîr, 9/199.

${ }^{96}$ Bk. Beyhakî, Ma'rifetü's-sünen, 12/320.
} 
nikâhı hiçbir şekilde helal değildir. Nikâh olarak anılsa da böyle bir evlilik, zina olup had gerektirir. $\mathrm{Bu}$ evliliği helal gördüğü ve dolayısıyla mürted olduğu için böyle birinin öldürülmesinin emredildiği görüşü de fasittir. Haddi gerekli görmeyenlere göre şüphe, cinsî teması mubah kılan nikâhın şeklen varlığıdır. Batıl olsa bile bu nikâh, haddi düşürecek bir şüphe oluşturur. Had düşse bile failleri şiddetli bir şekilde cezalandırılır. ${ }^{97}$

Burada usul açısından bir ihtilaf söz konusudur. Şöyle ki Ebû Hanîfe'ye göre kaide şudur: Ehli tarafından, gözetilen maksatlarını gerçekleştirebilecek bir mahalle/kadınla yapılan nikâh, kişiye haddin uygulanmasına engel teşkil eder. Nikâh ister haram ister helal olsun, haramlığı hakkında ister ihtilaf ister ittifak bulunsun, ister kişi bunun helal olduğunu sanıp karıştırdığını iddia etsin ister haramlığını bilsin fark etmez. Cumhurun ve İmâmeyn'in dayandıkları kaide ise şudur: Yapılan nikâh ebediyen haram olan veya haram olduğunda icmâ bulunan bir nikâh ise had gerekir. Zira böyle bir nikâhta cinsî münasebet, şüphe bulunmayan ve haramlı̆̆ kesin olan bir mahalle denk gelmiştir. Şayet nikâh ebediyen haram olmayan ve haram olup olmadığı hakkında şüphe bulunan bir türden ise o zaman had gerekmez. ${ }^{98}$ Hanefîlerde fetva İmâmeyn'e göre verilmiștir. Fakat İbn Âbidîn (v. 1252/1836) tüm şerhlerde tercih edilen görüşün Ebû Hanîfe'ye ait olduğu ve dolayısıyla fetvanın buna göre verilmesinin efdal olacağı kanaatindedir. ${ }^{99}$ Şâfiîlere göre ise bir kişi, zina yapmak için bir kadını kiralar ve onunla zina yaparsa ya da haram olduğuna inandığı halde mahremi olan bir kadınla gayrimeşru ilişkide bulunursa kendisine had cezası verilmesi gerekir. Zira böyle bir akdin o kadın ile cinsî münasebet kurmak hususunda herhangi bir etkisi bulunmayıp o akdin varlığı ve yokluğu aynıdır. ${ }^{100}$

\subsection{Hanbelîlerin Görüşü}

Ahmed b. Hanbel'e (v. 241/855) göre nikâhın hakiki anlamı hem akit hem de cinsî münasebettir. ${ }^{101}$ Nisâ, 22. ayet umum ifade ettiğinden baba, cinsî münasebette bulunsun veya bulunmasın fark etmez, üvey anne ile evlenmek haram olur. ${ }^{102}$ Mahremlerle evlenme fiili zinadan daha kötü olduğundan bu durum مقتاً diye ifade edilmiştir. Bu yüzden tercih edilen görüş, bekâr olsa bile böyle birinin her halükarda öldürülmesi gerektiğidir. Zinada durum böyle olmayıp bekârlar recmedilmezler. Ayrıca akit sahih olmalıdır. Zira sahih olmayan akit, akit olarak isimlendirilemez. Duhul ve halvet olmasa bile sırf akitle üvey anne haram olur. Helal veya haram

\footnotetext{
${ }^{97}$ Ebû Süleymân el-Hattâbî, Meâlimü's-sünen (Halep: el-Matbaatü'l-İlmiyye, 1932), 3/328-329.

${ }^{98}$ Kâsânî, Bedâi', 7/35; Şirbinî, Muğni'l-muhtâc, 5/445-446; Şîrâzî, Mühezzeb, 2/268; Muhammed b. Ahmed ed-Desûkî, Hâşiye (b.y.: Dârü'l-Fikr, ts.), 4/314; İbn Kudâme, Muğnî, 8/182.

${ }^{99}$ İbn Âbidîn, Reddü'l-Muhtâr, 4/24.

${ }^{100}$ Vehbe b. Mustafa ez-Zühaylî, el-Fıkhu'l-İslâmî ve edilletuhu (Dımaşk: Dârü'l-Fikr, ts.), 7/5354-7355.

${ }^{101}$ Merdâvî, Ali b. Süleyman, el-İnsâf, (b.y.: Dâru İhyâi't-Türâsi'l-Arabî, ts.), 8/5.

${ }^{102}$ Abdurrahman b. İbrahim el-Makdisî, el-‘Udde şerhu'l-'Umde, (Kâhire: Dârü'l-Hadîs, 2003), 1/399.
} 
olsun fark etmez cinsî münasebetle hürmet-i musâhare sabit olur. ${ }^{103}$ Ahmed b. Hanbel, makt nikâhı yapan kişinin öldürülüp malının alınması gerektiği kanaatindedir. Zira Hz. Peygamber’in, böyle birinin öldürülüp malının alınmasını emrettiği rivayet edilmiştir. Oğlun, babasının üç kez boşadığı, liân yaptığı veya bilerek cinsî münasebette bulunduğu kadınlar ile nikâhlanması da böyledir. ${ }^{104}$

Hanbelîlerin esas aldığı hadisin farklı rivayetleri vardır. ${ }^{105}$ Örneğin Yezîd b. el-Berâ'nın babasından yaptığı rivayet şöyledir: "Amcamın elinde sancak varken onunla karşılaştı̆ı̆mda nereye gittiğini sordum. Bana şöyle cevap verdi: "Rasûlullah (s.a.v.) beni, babasının hanımıyla evlenen birini öldürüp malını da (ganimet) olarak almam için gönderdi." ${ }^{106} \mathrm{Bu}$ rivayetlerin sahih olduğu ifade edilmiştir. ${ }^{107}$

Hanbelî hukukçuların esas aldığı rivayetlerden hareketle şöyle denilmiştir: Üvey annesiyle cinsî münasebette bulunduğu için değil, cinsî münasebeti helal kılan evlilik akdinde bulunduğu için ilgili şahsın öldürülmesi ve malının alınması emredilmiştir. Zira bu rivayetlerde cinsî münasebet ve recm söz konusu edilmemiştir. Zina, sahibini kâfir değil günahkâr yapar. Ayrıca öldürülüp malının alınması, zina yapan birine uygulanacak bir ceza değildir. Öyleyse bu şahıs, haram kılındığı ve bu fiilin haram olduğunu bildiği halde böyle bir nikâh yaparak Allah'ın hükmünü inkâr edip mürted olmuş ve kendisine ilgili hükümler tatbik edilmiştir. Dolayısıyla haram olan bu fiili helal görmeksizin sırf nikâh akdinde bulunduğu için kişi öldürülmez. ${ }^{108}$

\section{Değerlendirme ve Sonuç}

$\mathrm{Bu}$ çalışmada câhiliye dönemi gayrimeşru nikâh türleri arasında spesifik bir örnek olarak sunulan makt nikâhı üzerinden bir incelemeye gidilmiş olsa bile, manevi birer hastalık olmaları hasebiyle sunulan diğer gayrimeşru nikâh ve birliktelik türleri de izah edilmiştir. Câhiliye döneminde belki de sosyal baskı gözetilmiş olacak ki gayrimeşru ilişkilere nikâh kisvesi altında meşru bir yön kazandırma cihetine gidilmiştir. Buna rağmen İslamiyet'ten önce Araplarda evlilik hayatında bir disiplinin söz konusu olmadığı anlaşılmaktadır. İslâm, bu belirsizliği disipline ederek evlilik gibi önemli bir müesseseye hukukî statüsünü kazandırmış ve gayrimeşru tüm birliktelikleri

\footnotetext{
${ }^{103}$ Buhûtî, Mansur b. Yûnus, er-Ravdu'l-murbi', (b.y.: Dârü'l-Müeyyid, ts.), 1/519; Üseymîn Muhammed b. Sâlih. Şerhu'l-mumti' alâ Zâdi'l-müstaknî, (b.y.: Dârü İbni'l-Cevzî, 1428), 12/118; İbrahim b. Muhammed İbn Müflih, el-Mübdi' fî şerhi'l-Mukni', (Beyrut: Dârü'l-Kütübi'l-i̇lmiyye, 1997), 6/130.

104 ed-Demîrî, en-Necmü'l-vehhâc, 9/110.

105 "Rasûlullah (s.a.v.), Muaviye’nin dedesini, üvey annesi ile gerdeğe giren bir adama, onun boynunu vurup malının bește birisini alması için göndermiştir." Bk. Ahmed b. el-Hüseyn el-Beyhakî, Márifetü's-sünen ve'l-âsâr, (Beyrut: Dâru Kuteybe, 1991), 12/320.

${ }^{106}$ Ebû Dâvûd, "Hudûd”, 27 (4457); Nesâî, "Nikâh", 58.

${ }^{107}$ İbn Kayyim el-Cevziyye, Zâdu'l-me‘̂ad, (Beyrut: Müessesetü'r-Risâle, 1994), 5/13.

${ }^{108}$ Ebû Zekeriyyâ en-Nevevî, Mecmû' şerhu'l-Mühezzeb. (b.y.: Dârü'l-Fikr, ts.), 20/26; Zekeriyya b. Mesud el-Ensarî, elLübâb, thk. Abdulaziz el-Murâd, (Beyrut: Dârü’ş-Şâmiyye, 1994), 2/739-740.
} 
ve bunlar neticesinde vuku bulan nikâhları ilga etmiş, Araplarca da rağbet gören sahih evliliği korumuş, bunun haricindeki nikâh ve birliktelik türlerini gayrimeşru addetmiştir. Makt nikâhı da bunlardan olup Nisâ Sûresi'nin 22. ayetiyle müstakil olarak haram kılınmıştır. İslâm hukukçularının bu ayette zikri geçen nikâh kelimesine farklı anlamlar yüklemeleri, hükümler üzerinde de etkili olmuştur.

İslâm hukukuna göre usulün eşleri ve dolayısıyla üvey anneler ile evliliğin yasak olması için sadece baba ile sahih nikâh akdinin yapılmış olması yeterli olup zifaf şart görülmemiştir. ${ }^{109}$ Bununla birlikte böyle bir nikâhın sahih veya fasid oluşu, kişinin, babasının zina yaptığı kadınla evlenmesinin haram olup olmadığı, şayet böyle bir evlilik yaptığında kendisine ne tür bir cezanın verileceği gibi hususlar ihtilaflıdır. Bu nikâhın sahih veya fasit oluşu hususundaki görüş ayrılıkları neticesinde Hanefîler fasit akdin haramlık doğurmayacağı, Mâlikîler ise doğuracağı kanaatine varmışlardır. İmam şâfiî̀ye göre böyle bir zina, haramlık oluşturmazken Hanefî ve Hanbelî hukukçulara göre haramlık oluşturmaktadır. Şâfiî mezhebi, bu hususu bir evlilik engeli olarak görmedikleri için diğer mezheplerden ayrılmaktadır. Burada, müşterek bir lafız olan nikâh kelimesine yüklenen anlamların, görüş ayrılıklarına sebep olduğu anlaşılmaktadır. Bu anlamda mezkûr kelimenin luğavî delâletini esas alanlar, zinanın da haramlık doğuracağı; şerîi delâletini esas alanlar ise haramlık doğurmayacağı yönünde görüş beyan etmişlerdir. Bu görüşte olanlara göre nesep, zina ile sabit olamaz. ${ }^{110}$

Görüş ayrılıklarından birini de böyle bir nikâhın failine ne tür bir ceza uygulanacağı hususu oluşturmaktadır. Ebû Hanîfe'ye göre haram olduğu bilinsin veya bilinmesin nikâh şüphesi had uygulanmasına mani iken İmâmeyn'e göre haramlığının bilinmesi durumunda zina haddi uygulanmalıdır. İslâm hukukçularının çoğunluğu makt nikâhının failine zina haddi uygulanması gerektiği kanaatinde iken Hanbelîler bazı rivayetlerden hareketle failinin öldürülmesi ve malının da alınması yönünde görüş beyan etmişlerdir. Ne var ki bu rivayetlerin, haram olduğunu bilerek böyle bir evlilik yaptığı için mürted olanlar hakkında olduğu ifade edilmişse de karşıt görüşler de serdedilmiştir.

Genel olarak İslâm'da evlilik hususunda yapılan hukukî düzenlemelerin, kadının lehine olduğunu söylemek mümkündür. Evlilik hususunda kadın, İslâm ile kişiliğini kazanmış ve nikâh akdinde taraflardan biri konumuna getirilmiştir. ${ }^{111}$ Önceleri kadın, mirasa konu olan bir meta iken

\footnotetext{
109 Serahsî, Mebsût, 4/198-199; Ali b. Ebî Bekr el-Merğînânî, el-Hidâye, thk. Tallâl Yûsuf, (Beyrut: Dârü İhyâi'tTurâsi'l-Arabî, ts.), 1/186-187; Mevsılî, İhtiyâr, 3/85, 95, 105; Buhûtî, Mansûr b. Yûnus, Keşşâfü'l-kınâ‘ an metni'l-ïknâ', (b.y.: Dârü'l-Kütübi'l-İlmiyye, ts.), 5/77; Desûkî, Hâş̧iye, 2/259.

${ }^{110}$ İbn Rüşd, Ebû'l-Velîd, Bidâyetü'l-müctehid, (Kâhire: Dârü'l-Hadîs, 2004), 3/57-59.

${ }^{111}$ Kahveci, İslâm Aile Hukuku, 24.
} 
İslâmiyet, kadını bu pozisyondan kurtarıp mirasçı kılmıştır. ${ }^{112}$ Boşanma veya kocanın ölmesi durumlarında oluşabilecek mağduriyetleri önlemek adına kadının mehir hakkı, yeni düzenlemeler ile daha iyi korunmuştur. Ayrıca boşamaya da bir disiplin getirilerek ${ }^{113}$ erkeğin olur olmaz durum ve sayılarda boşamasının önü kesilmiş, kadının onur ve haysiyeti muhafaza edilmiştir.

\section{Kaynakça}

Adevî, Ebü'l-Hasen Ali b. Ahmed. Hâşiyetü'l-'Adevî ala şerhi Kifâyeti't-Tâlib er-Rabbânî. 2 Cilt. Beyrut: Dârü'l-Fikr, 1994.

Alûsî, Şihâbuddîn. Rûhu'l-meânî. thk. A. Abdülbârî Atiyye, 16 Cilt. Beyrut: Dârü'l-Kütübi'l-illmiyye, 1415.

Atar, Fahrettin. "Nikâh". Türkiye Diyanet Vakfi İslâm Ansiklopedisi. 33/112-117. İstanbul: TDV Yayınları, 2007.

Aydın, M. Âkif. “Aile”. Türkiye Diyanet Vakfı İslâm Ansiklopedisi. 2/196-200. İstanbul: TDV Yayınları, 1989.

Aynî, Ebû Muhammed Bedrüddîn. 'Umdetü'l-kâri' fi șerhi Sahîhi'l-Buhârî. 25 Cilt. Beyrut: Dâru İhyâi'tTurâsi'l-Arabî, ts.

Azîmâbâdî, Ebü't-Tayyib. Avnu'l-ma'bûd. 14 Cilt. Beyrut: Dârü'l-Kütübi'l-İlmiyye, 1415.

Begavî, Muhammed el-Ferrâ'. et-Tehzîb fî fikhi'l-İmâm eş-Şâfî̀, thk. Âdil Ahmed Abdulmevcûd-Alî Muhammed Muavvez, 8 Cilt. Beyrut: Dârü'l-Kütübi'l-İlmiyye, 1997.

Beydâvî, Nâsiruddîn. Envâru't-tenzîl. thk. M. Abdurrahman el-Mar'aşlî, Beyrut: y.y., 1418.

Beyhakî, Ahmed b. el-Hüseyn. Ma'rifetü's-sünen ve'l-Âsâr. thk. A. Emin Kal'acî, 15 Cilt. Beyrut: Dâru Kuteybe, 1991.

Buhârî, Muhammed b. İsmail. Sahîh. İstanbul: Çağrı Yayınları, 1992.

Buhûtî, Mansûr b. Yûnus. Keş̧̧âfü'l-kınâ‘ an metni'l-íknâa 6 Cilt. b.y.: Dârü'l-Kütübi'l-ílmiyye, ts.

Buhûtî, Mansur b. Yûnus. er-Ravdu'l-Murbi 'Şerhu Zâdi'l-Müstakni', b.y.: Dârü'l-Müeyyid, ts.

${ }^{112}$ Aydın, “Aile”, 2/198.

${ }^{113}$ el-Bakara, 2/229. 
Kıylık, Sosyal Bir Hastalık ve Gayrimeşru Bir Evlilik: "Nikâhu'l-Makt"

Cessâs, Ahmed b. Ali. Ahkâmu'l-Kur'ân. thk. M. Sadık el-Kamhâvî, Beyrut: Dâru İhyâi't-Turâsi'lArabî, 1405.

Cevâd Ali. el-Mufassal fí târîhi'l-‘Arab kable'l-İslâm. 20 Cilt. b.y.: Dâru's-Sâkî, 4. Basım, 2001.

Cezîrî, Abdurrahman. el-Fıkh ‘ale'l-mezâhibi'l-erbaa. 5 Cilt. Beyrut: Dârü'l-Kütübi'l-İlmiyye, 2003.

Çağatay, Neşet. İslâm'dan Önce Arap Tarihi ve Câhiliye Çağı. Ankara: AÜIIF. Yayınları, 1957.

Demircan, Adnan. "Câhiliye İle İslâm Nikâh Uygulamaları Arasında Benzerlikler ve Farklılıklar Farklı Bir Yaklaşım-”. Dinlerde Nikâh. İstanbul: İSAV, 2012.

Desûkî, Muhammed b. Ahmed. Hâşiyetu'd-Desûkî ale'ş-Şerhi'l-Kebîr. 4 Cilt. b.y.: Dârü'l-Fikr, ts.

Ebû Ca‘fer, Muhammed b. Habîb. el-Muhabber. Beyrut: Dârü'l-Âfâki'l-Cedîde, ts.

ed-Demîrî, Ebü'l-Bekâ Kemâlüddin. en-Necmu'l-vehhâc fî şerhi'l-Minhâc. 10 Cilt. b.y.: Dârü'l-Minhâc, 2004.

el-Alûsî, Mahmûd Şükrî. Bulûğu'l-ereb fî Ma'rifeti ahvâli'l-Arab. 4 Cilt. b.y.: y.y., 2. Basım, ts.

el-Endülûsî, Ebû Hayyân. el-Bahru'l-muhît fi't-tefsîr. thk. S. Muhammed Cemîl, 10 Cilt. Beyrut: Dârü'lFikr, 1420.

el-Ensarî, Zekeriyya b. Mesud. el-Lübâb. thk. Abdulaziz el-Murâd, 2 Cilt. Beyrut: Dârü’ş-Şâmiyye, 3. Basım, 1994.

el-Ezdî, Ebû Bekr. Cemheretu’l-luğa. thk. R. M. Ba‘lebekî, Beyrut: Dârü'l-İlm li'l-Melâyîn, 1987.

Ezherî, Ahmed b. Ğânim. el-Fevâkihu'd-dîvânî. 2 Cilt. b.y.: Dârü'l-Fikr, 1995.

Fayda, Mustafa. "Câhiliye". Türkiye Diyanet Vakfi İslâm Ansiklopedisi. 7/17-19. İstanbul: TDV Yayınları, 1993.

Hallâf, Abdulvehhâb, Ahkâmu'l-ahvâli'ş-şahsiyye. Kâhire: Dârü'l-Kütübi'l-Mısriyye, 2. Basım, 1938.

Hasanov, Eldar. “Yahudi Hukukunda Evlilik Engelleri”. Dinlerde Nikâh. İstanbul: İSAV, 2012.

Hattâbî, Ebû Süleymân. Meâlimü’s-Sünen. Halep: el-Matbaatü'l-İlmiyye, 1932.

Heyet (H. Karaman vd.). Kur'ân Yolu Türkçe Meâl ve Tefsir. 5 Cilt. Ankara: DİB Yayınları, 2. Basım, 2006.

İbn Âbidîn, Muhammed Emin. Reddü'l-muhtâr 'ale'd-Dürri'l-Muhtâr. Beyrut: Dârü'l-Fikr, 1992. 
Kiylı, A Social İllness And An İllegal Marriage: "Nikâh al Makt"

İbni Aşûr, Tâhir. Makâsıdu'ş-şerîati'l-İslâmiyye. thk. M. el-Habîb b. el-Hûce, 3 Cilt. Katar: Vizâretu'lEvkâf ve'ş-Şuûni'l-i̇slâmiyye, 2004.

İbn Kayyim el-Cevziyye. Zâdu’l-me‘âd. 5 Cilt. Beyrut: Müessesetü’r-Risâle, 1994.

İbn Kudâme, Muvaffakuddin. el-Muğnî. Kâhire: Mektebetü'l-Kâhire, 1968.

İbn Manzûr, Ebü'l-Fazl Cemâlüddîn. Lisânü'l-'Arab. Dâru Sâdır, Beyrut 1414.

İbn Müflih, İbrahim b. Muhammed. el-Mübdi' fî șerhi'l-Mukni‘. 8 Cilt. Beyrut: Dârü'l-Kütübi'l-ìlmiyye, 1997.

İbn Nüceym, Zeynüddîn. el-Bahru'r-râik şerhü Kenzi'd-Dekâik. 8 Cilt. b.y.: Dârü'l-Kitâbi'l-İslâmî, 2. Basim, ts.

İbn Rüşd, Ebû'l-Velîd. Bidâyetü'l-müctehid. 4 Cilt. Kâhire: Dârü'l-Hadîs, 2004.

İbn Rüşd el-Kurtubî. el-Mukaddimâtü'l-mumehhidât. 3 Cilt. Beyrut: Dârü'l-Ğarbi'l-İslâmî, 1988.

İbnu'l-Verdî el-Ma'rî. Târîhu İbni'l-Verdî. 2 Cilt. Beyrut: Dârü'l-Kütubi'l-İlmiyye, 1996.

İbnü’l-Esîr, Mecduddin. en-Nihâye fíğarîbi'l-hadîs. Beyrut: el-Mektebü'l-i̇lmiyye, 1979.

İbnü'l-Hümâm, Kemâlüddîn. Fethü'l-kadîr. 10 Cilt. b.y.: Dârü'l-Fikr, ts.

İmâduddin, Ebü'l-Fidâ. el-Muhtasar fí ahbâri'l-beșer. 4 Cilt. Mısır: el-Matbaatu'l-Hüseyniyye, ts.

Kahveci, Nuri. İslâm Aile Hukuku. İstanbul: Hikmetevi Yayınları, 2014.

Kâsânî, Alâüddîn Ebû Bekr b. Mes'ûd. Bedâiu's-sanâi fî tertîbi'ş-şerâi'. 7 Cilt. Beyrut: Dârü'l-Kütübi'lİlmiyye, 2. Basım, 1986.

Kastallânî, Ahmed b. Muhammed. İrşâdu's-sâri. 10 Cilt. Mısır: el-Matbaatu'l-Kübrâ, 1323.

Köse, Saffet. "Câhiliye Arap Toplumunda Kocaların Hanımlarına Yaptıkları Bazı Haksızlıklar ve İslâm'ın Getirdiği Hukukî Düzenlemeler”. Konya: Mehir, 1999.

Kurtubî, Muhammed b. Ahmed. el-Câmi li ahkâmi'l-Kur'ân. thk. A. el-Burdûnî-İ. Atfeyş, Kâhire: Dârü'l-Kütübi'l-Misriyye, 1964.

Makdisî, Abdurrahman b. İbrahim. el-'Udde şerhu'l-'Umde, Kâhire: Dârü'l-Hadîs, 2003.

Mansûr b. Yûnus el-Buhûtî. Keşşâüu'l-kınâ‘. Beyrut: Dârü’l-Fikr, 1982. 
Kıylık, Sosyal Bir Hastalık ve Gayrimeşru Bir Evlilik: "Nikâhu'l-Makt"

Mâverdî, Ebü'l-Hasen. Hâvi'l-kebîr. thk. A. Muhammed Muavviz-A. Abdulmevcûd, 19 Cilt. Beyrut: Dârü'l-Kütübi'l-İlmiyye, 1999.

Merdâvî, Ali b. Süleyman, el-İnsâffî Ma'rifeti'r-râcih mine'l-hilâf, 12 Cilt. Dâru İhyâi't-Türâsi'l-Arabî, 2. Basım, ts.

Merğînânî, Ali b. Ebî Bekr. el-Hidâye. thk. Tallâl Yûsuf, 4 Cilt. Beyrut: Dâru İhyâi't-Turâsi'l-Arabî, ts. Mevsılî, Abdullah b. Mahmûd. el-İhtiyâr li ta'lîli'l-Muhtâr. thk. M. Ebû Dakîk, 5 Cilt. Kâhire: y.y., 1937.

Müslim b. Haccâc. Sahîh. İstanbul: Çağrı Yayınları, 1992.

Nevevî, Ebû Zekeriyyâ. el-Mecmû' șerhu'l-Mühezzeb. 20 Cilt. b.y.: Dârü'l-Fikr, ts.

Râfiî, Ebü'l-Kāsım Abdülkerîm b. Muhammed b. Abdilkerîm er-Râfiî el-Kazvînî, el-Azîz şerhu'l-Vecîz. thk. Ali Muhammed İvez-Âdil Ahmed Abdulmevcûd, 13 Cilt. Beyrut: Dârü'l-Kütübi'lİlmiyye 1997.

Rağıp el-İsfehânî. el-Müfredât fi ğarîbi'l-Kur'ân. thk. S.A. ed-Davidî, Beyrut: Dârü'l-Kalem, 1412.

Râzî, Zeynüddin Ebû Abdillah. Muhtâru's-sıhâh. thk. Y. eș-Şeyh Muhammed, el-Beyrut: Mektebetu'lAsriyye, 1999.

Remlî, Şemsuddin Muhammed. Nihâyetu'l-muhtâc ila şerhi'l-Minhâc. 8 Cilt. Beyrut: Dârü'l-Fikr, 1984.

Reşid Rizâ Muhammed. Tefsîru'l-Kur'âni'l-Hakîm. by.: y.y., 1990.

Sarıcık, Murat. "Câhiliye Nikâhı müt’a ve Diğer Câhiliye Nikâhları”. SDÜIFD. 3 (1996).

Sâvî, Ebü'l-Abbas. Bulğatu's-sâlik li akrabi'l-mesâlik, 4 Cilt. b.y.: Dârü'l-Meârif, ts.

Semerkandî, Alâuddîn. Tuhfetu'l-fukahâ. 3 Cilt. Beyrut: Dârü'l-Kutubi'l-ilmiyye, 1994.

Serahsî, Ebû Bekir Şemsü’l-Eimme. el-Mebsût. Beyrut: Dârü'l-Ma'rife, 1993.

Suyûtî, Celâleddin. Tefsîru'l-Celâleyn. Kâhire: Dârü'l-Hadîs, ts.

Şâfiî, Muhammed b. İdris. el-Ümm. Beyrut: Dârü'l-Ma'rife, 1990.

Şevkânî, Muhammed b. Ali. Fethü'l-kadîr. 6 Cilt. Beyrut: Dâru İbni Kesîr, 1414.

Şeybânî, Ebû Abdillah. el-Asl. thk. Mehmet Boynukalın, 12 Cilt. Beyrut: Dâru İbni Hazm, 2012. 
Kıylık, A Social İllness And An İllegal Marriage: "Nikâh al Makt"

Şirbînî, Ahmed el-Hatîb. Muğni'l-muhtâc ila ma'rifeti meâni elfâzi'l-Minhâc. 6 Cilt, b.y.: Dârü'l-Kütübi'lİlmiyye, 1994.

Taberî, Muhammed b. Cerir. Câmiu'l-beyân fì te'vîli'l-Kur'ân. thk. A. Muhammed Şâkir, 24 Cilt. b.y.: Müessesetü'r-Risâle, 2000.

Tahâvî, Ebû Ca'fer. Muhtasaru ihtilâfi'l-ulemâ. thk. A. Nezir Ahmed, 5 Cilt. Beyrut: Dârü'l-Beşâiri'lİslâmiyye, 1417.

Takiyyuddîn, Ebû Bekr b. Muhammed. Kifâyetü'l-ahyâr fî halli ğâyeti'l-ihtisâr. thk. A. Abdulhamid-M. Vehbi Süleyman, Dımaşk: Dârü’l-Hayr, 1994.

Tayşi, M. Serhan. "Kıyâfe”. Türkiye Diyanet Vakfi İslâm Ansiklopedisi. 25/508. Ankara: TDV Yayınları, 2002.

Termânînî, Abdusselâm. ez-Zevâc 'inde'l-Arab, fill-câhiliyye ve'l-íslâm. Kuveyt: y.y., 1984.

Üseymîn Muhammed b. Sâlih. Şerhu'l-mumti' alâ Zâdi'l-müstaknî. 15 Cilt. b.y.: Dârü İbni'l-Cevzî, 1428. Zemahşerî, Ebü'l-Kâsım. el-Keşşâf. Beyrut: Dârü'l-Kütübi'l-Arabî, 1407.

Zebîdî, Ebubekir b. Ali. el-Cevheretu'n-neyyire. b.y.: el-Matbaatu'l-Hayriyye, 1322.

Zebîdî, Muhammed. Tâcu'l-arûs. b.y.: Dârü'l-Hidâye, ts.

Zeydân, Abdulkerîm. el-Medhal. Beyrut: Müessesetü'r-Risâle, 16. Basım, 2002.

Zeylaî, Fahreddin Osman b. Ali. Tebyînü'l-hakâik. Kâhire: Matbaatü'l-Kübrâ, 1893.

Zühaylî, Vehbe b. Mustafa. el-Fıkhu'l-İslâmî ve edilletuhu. 10 Cilt. Dımaşk: Dârü'l-Fikr, 4. Basım, ts.

https://www.almerja.com/reading.php?idm=71395 (Erişim Tarihi: 20.05.2021) 
Kıylık, Sosyal Bir Hastalık ve Gayrimeşru Bir Evlilik: "Nikâhu'l-Makt"

\section{A Social İllness And An İllegal Marriage: "Nikâh al Makt"}

\section{Dr. Mustafa Harun KIYLIK}

\section{Extended Summary}

The family is the smallest building block of society. A good family is of great importance for any nation that cares about its future. In general, societies are based on the establishment of the family with a valid marriage. However, in this study, we discussed the types of marriage and illegitimate union that occurred in the period of ignorance in general. Then, we tried to explain how Islam generally abolished illegitimate marriages and unions in the jahiliyyah period, and specifically the "nikâh al makt", which is one of the types of marriages in the jahiliyyah period, in terms of Islamic law.

In our study, we saw that there was no discipline in the family structure of the Arab society of the jahiliyyah period. In that period, there were so many different marriages and illegitimate unions that we shudder when we hear them. Of course, this situation constitutes one of the indicators that women were not valued at that time and that women were perceived as a commodity. Although this is the case, it is understood that social pressure made it necessary to make it legal to be with women at that time. It is seen that the types of marriage and union that emerged in this direction do not go beyond making the woman even more worthless.

In this period, which was far from revelation, there were behaviors that would cause outrage in social and moral fields. Among these, there were practices that became established, as well as types of marriage and illegitimate union, which were not seen as moral even at that time and were not inclined by everyone. As this is the case, divine intervention in this deviated society was not delayed, and the wrong practices in family life were also removed. If there are correct practices, they are taken as they are, and if possible, vicious practices are cleared of these vicious elements and placed on a sound ground.

Since lineage and the preservation of generations are very important in Islam, first of all, it is explained in a special way with whom a person cannot marry, and it is revealed which of them permanently and which temporarily prevents marriage. Although different measures were taken regarding family life, we did not touch on these issues because they went beyond our scope of study.

The "nikah al makt", which is the subject of our study, appears as a type of marriage practiced in the period of ignorance and prohibited by Islam. In the classification made in the 
form of permanent and temporary marriage barriers in Islam, "nikah al makt" is among the permanent marriage barriers. This type of marriage is discussed in detail within the framework of the verse in which it is prohibited. Then, in the context of this verse, the issues that are agreed upon and the situations that cause differences of opinion are explained. In this context, it has been tried to explain the meanings given to the word marriage in the verse in question and the legal consequences of these different meanings and what kind of punishment will be given to the person who makes such a marriage.

"Makt marriage" is actually a type of marriage that expresses the marriage of a person to his stepmother after his father's death. This concept means a marriage of hate. The reason for its name is explained as follows: After marrying his stepmother, this marriage causes the son to hate his father. For, in general, a man who marries a woman hates that woman's first husband. It is understood that this marriage is not desirable for both the son and the stepmother, but that the parties have to endure such a hardship under social pressure. This practice has completely abolished it with the following verse of Surah an-Nisa: "And marry not women whom your fathers married,- except what is past: It was shameful and odious,- an abominable custom indeed."

However, Islamic jurists are in disagreement about the word marriage mentioned in this verse. In this sense, there are jurists who give the meaning of contract to the word in question, as well as those who give the meaning of sexual relationship.

In Islamic law, in order for marriage with stepmothers to be prohibited, only the marriage contract with the father is considered sufficient, and "zifaf", that is, having sexual intercourse on the wedding night, is not required. However, there have been differences of opinion on whether it is haram for a person to marry the woman whose father has committed adultery, and what kind of punishment will be given to him if he makes such a marriage. In this study, the subject has been examined in detail within the framework of the issues that cause differences of opinion and some conclusions have been reached.

Keywords: Islamic Law, Nikâhu'l-Maqt, Surah an-Nisaâ, Forbidden, Ignorance Perıd. 